KATARZYNA BIERNACKA-LICZNAR

iD https://orcid.org/0000-0003-0541-5005

Uniwersytet Wrocławski

katarzyna.biernacka-licznar@uwr.edu.pl

\title{
OPOWIEŚĆ O ŻYCIU I TWÓRCZOŚCI ZOFII ERNST (1918-1994)
}

\section{Abtract}

\section{On the Life and Work of Zofia Ernst}

My aim in this article is to present the life and work of Zofia Ernst, nee Kostanecka (19181994), a connoisseur of Italian culture and literature and an accomplished translator of Italian books for adults and children. In my argument, I draw on the ethnographic approach, using a common ethnographic tool: the qualitative interview (structured interview) to address important moments and events in Ernst's life. The focus on the life-story of one translator will help me depict the environment she lived and worked in as well as identify her embedment in particular familial and professional settings which crucially affected her work. I will also discuss Ernst's formative contribution to the image of Italian literature in Poland in the years 1953-1979, i.e. in the period of her translation activity.

Keywords: Zofia Ernst, literary translation, ethnographic approach, qualitative interview, Nasza Księgarnia

Słowa kluczowe: Zofia Ernst, przekład literacki, metoda etnograficzna, wywiad jakościowy, Nasza Księgarnia

${ }^{1}$ Artykuł ten jest zmienioną i skróconą wersją artykułu pod tytułem Zofia Ernst (19181994): l'arte di vivere, l'arte di tradurre, który ukazał się w roku 2017 w czasopiśmie „Italica Wratislaviensia" 8(2), 2017, s. 11-36. 
Ze sztuk pięknych tylko literatura potrzebuje thumacza, bez którego autor jest zamknięty w granicach swojego państwa ${ }^{2}$.

Zofia Ernstowa

„Tłumacz, specjalnie zaś tłumaczka, to zjawisko, z nielicznymi wyjątkami, socjalne, klasowe, nie literackie" - tymi słowami Julian Tuwim w artykule Traduttore-traditore, opublikowanym po raz pierwszy w roku $1950 \mathrm{w}$ „książce-legendzie"3 Pegaz dęba, opisał osoby zaangażowane w opracowywanie przekładów (Tuwim 2008: 167). Zjawisku „tłumaczka” przypisał poeta szereg negatywnych cech, postulując jednocześnie stworzenie „kursów dla tłumaczy - szkoły prowadzonej przez doświadczonych znawców tej arcytrudnej sztuki (Tuwim 2008: 167)". W eseju Tuwim wytykał przedwojennym edytorom i tłumaczom liczne błędy i potknięcia, część tych uwag odnosiła się do tłumaczek, które podejmowały tego rodzaju pracę często z przyczyn ekonomicznych. Na początku XX wieku twórczość przekładowa nie była jeszcze traktowana jako zawód, tłumaczenie rzadko stanowiło jedyną formę zatrudnienia, choć bywały wyjątki, jak choćby przypadek Anieli Zagórskiej (por. Rajewska 2015). W Polsce międzywojennej zawód „tłumacz” oznaczał co prawda pewien prestiż, jednak tłumaczki nie czuły się jeszcze wtedy pełnoprawnymi uczestniczkami życia literackiego. Skromne wynagrodzenia wypłacane przez wydawców powodowały, że na taki rodzaj zarobkowania nie decydowali się zazwyczaj wybitni ludzie pióra (Miłosz 1999: 352), zadania opracowania przekładów literackich powierzano więc thumaczkom, które mimo warunków finansowych, podejmowały się tego zajęcia z umiłowania do danej kultury, literatury czy języka. Po drugiej wojnie światowej na polskiej scenie literackiej obok przedwojennych tłumaczy pojawiły się osoby, które

${ }^{2}$ Cytat zaczerpnięto z wywiadu udzielonego przez Zofię Ernstową Jerzemu Ciechanowiczowi. Zob. Kolory Włoch, w: „Życie Warszawy”, dodatek „Kultura”, 21-22 marca 1992, s. 10.

3 Tymi słowami określił książkę Tuwima Jerzy Bralczyk. Sam Tuwim w roku 1950, w przedmowie do książki wspominał, że rękopis Pegaza dęba przeleżał w walizie, wypchanej rękopisami wierszy i przekładów oraz dużą ilością innych materiałów stanowiących efekt pracy pisarza w latach 1914-1939, zakopanej w piwnicy jednego z warszawskich domów przez całą wojnę. Po zakończeniu działań wojennych Tuwimowi udało się odkopać ukryte przed wojną ,archiwum”. Ze wszystkich materiałów przetrwały tylko dwa pakiety: materiały do życiorysu Sotera Rozmiar Rozbickiego i manuskrypt książki Pegaz dęba. Książka ukazała się w roku 1950 w wydawnictwie Czytelnik, jej kolejne wydanie opublikowano dopiero w roku 2008. 
jeszcze przed wojną „,posiadły języki obce” i zaczęły świadczyć usługi dla wydawnictw.

Dotychczas życie i twórczość tłumaczek włoskiej literatury pięknej nie cieszyły się dużym zainteresowaniem polskich badaczy. $\mathrm{O}$ ich działalności przekładowej wiemy niewiele (Biernacka-Licznar 2016: 460-468), a jeśli pominiemy informacje zawarte w Słowniku biobibliograficznym współczesnych polskich pisarzy i badaczy literatury, encyklopediach PWN-u i Teatru Polskiego, to pozostaje nam niewiele źródeł umożliwiających odtworzenie ich życia i działalności.

Jeżeli biografię potraktujemy jako wydarzenie unikatowe umieszczone na osi czasu, to do jej pełnego odczytania niezbędne wydaje się zastosowanie podejścia etnograficznego. Najlepszym rozwiązaniem byłoby oddanie głosu samym tłumaczom, jednak nie zawsze jest to możliwe. Dzięki zastosowaniu metod badawczych wywodzących się z etnografii, na przykład wywiadów, obserwacji (uczestniczących i nieuczestniczących), analizy różnych dokumentów (np. archiwów tłumaczy, korespondencji, archiwów wydawniczych), możemy dotrzeć do często nieznanych faktów z ich życia.

Metody etnograficzne zostały już wykorzystane do badań dotyczących statusu tłumaczy (Dam, Zethsen 2010; Solová 2015) i ich pracy (Risku, Windhager 2013), jednak w odniesieniu do biografii polskich tłumaczek włoskiej literatury można wymienić zaledwie dwie prace, które zostały przeprowadzone z wykorzystaniem metod etnograficznych w ostatnich latach (Porębska 2017, Biernacka-Licznar 2017). W niniejszym artykule przedstawiam wyniki badań otrzymane z wykorzystaniem techniki wywiadu jako jednej z metod badawczych stosowanych w etnografii (Kvale 2012). Wywiad będący rozmową, której struktura i cel są określone przez osobę przeprowadzającą wywiad, ma na celu uzyskanie opisu świata życia respondenta lub osoby, którą respondent zna/znał (Kvale 2012: 37).

Dotychczas w badaniach poświęconych Zofii Ernstowej skoncentrowałam się na przeprowadzeniu wywiadów z osobami z jej najbliższego otoczenia: synem i synową, jak również z ludźmi, z którymi miała kontakt zawodowy: z poetą i tłumaczem z języka włoskiego Jarosławem Mikołajewskim i z prozaikiem, tłumaczem literatury włoskiej Eugeniuszem Kabatcem, który w latach 1968-1974 był radcą do spraw kultury w ambasadzie PRL w Rzymie ${ }^{4}$. Otrzymane w ten sposób informacje pozwoliły mi na opra-

${ }^{4}$ Dziękuję panu Tomaszowi Ernstowi, synowi Zofii Ernst, za możliwość wykorzystania w artykule fragmentów pamiętnika Jana Ernsta i użyczenie z domowego archiwum doku- 
cowanie dosyć szczegółowej biografii tłumaczki. Dopełnieniem artykułu mogłoby być ukazanie procesu podejmowania decyzji dotyczących selekcji i publikacji włoskich tekstów do tłumaczenia na język polski przez samą tłumaczkę i wydawnictwa w okresie jej działalności przekładowej. Cenne byłoby poznanie strategii i motywacji wydawców wobec importu włoskiej literatury pięknej i literatury dla dzieci i młodzieży. Ten obszar badań wymaga jednak przeprowadzenia kwerendy między innymi w Archiwum Akt Nowych w Warszawie w zespole Głównego Urzędu Kontroli Prasy, Publikacji i Widowisk (GUKPPiW), który od roku 2013 jest wyłączony z udostępniania. Ponadto z przeprowadzonych przeze mnie wstępnych badań w wydawnictwach, z którymi współpracowała Zofia Ernstowa, wynika, że nie zachowały się materiały archiwalne dotyczące jej działalności przekładowej. Jest to spowodowane między innymi tym, iż sama Ernstowa kontaktowała się osobiście bądź telefonicznie z redaktorami, więc nie zachowały się notatki i sprawozdania związane z powierzonymi jej do przekładu utworami.

Należy jednak podkreślić, iż z informacji uzyskanych od rodziny Zofii Ernstowej wynika, że to ona sama niejednokrotnie sugerowała redaktorom, które książki z włoskiej literatury warte są przekładu na język polski. Była do pewnego stopnia współodpowiedzialna za kształtowanie w Polsce obrazu włoskiej literatury.

Warto także pamiętać o tym, że w okresie Polski Ludowej relacje polsko-włoskie ulegały przemianom, których „rytm wyznaczany był przede wszystkim przez kształtowanie się dwubiegunowego podziału świata na zwalczające się bloki polityczno-militarne" (Pasztor, Jarosz 2013: 17), a nawiązywanie stosunków kulturalnych w okresie tuż powojennym i w latach kolejnych nie było procesem łatwym. W apogeum stalinizmu wymiana naukowa, kulturalna i artystyczna między Warszawą i Rzymem była skutecznie reglamentowana, po roku 1958 kontakty kulturalne ożywiły się, a począwszy od roku 1960 były dosyć dynamiczne (Bernatowicz 1990). Działalność zawodowa Ernstowej przypadła więc na okres niezwykle ciekawy z punktu widzenia wzajemnych stosunków polsko-włoskich.

mentów osobistych Zofii Ernstowej. Składam wyrazy podziękowania pani Marii Ernst, Jarosławowi Mikołajewskiemu i Eugeniuszowi Kabatcowi za udzielone mi informacje i udostępnione materiały. 
22 marca 1918 roku w Warszawie przyszła na świat Zofia Kostanecka herbu Wieruszowa. Jej ojcem był Antoni Kostanecki, profesor ekonomii i drugi w historii rektor Uniwersytetu Warszawskiego, matką - Anna Kostanecka z domu Geyer, pochodząca z rodziny bogatych fabrykantów łódzkich. W roku 1936 Zofia Kostanecka ukończyła Gimnazjum Jadwigi Kowalczykówny w Warszawie i w październiku podjęła studia w warszawskiej Szkole Głównej Handlowej przy ulicy Rakowieckiej 6. Studiów tych nie ukończyła. W roku 1937 rodzice wysłali dziewiętnastoletnią Zofię do Rzymu na studia w zakresie historii sztuki, pragnęli także, aby córka pogłębiła znajomość języka włoskiego, który znała od wczesnej młodości. W Rzymie mieszkała bliska rodzina matki Zofii, Antoniowie Aluffi-Pentini. Zofia wraz z innymi panienkami z Polski zamieszkała w Rzymie w Casa Santa Maria Maggiore przy via Regina Giovanna di Bulgaria 23, u sióstr urszulanek szarych. W Rzymie w roku 1938, a dokładnie 9 lutego, na balu kostiumowym w konsulacie polskim, Zofia poznała swojego przyszłego męża, Jana Ernsta (Ernst 1988, t. 1: 254) . Miała wtedy dwadzieścia lat, „była ładna, zgrabna i o pełnych wyrazu oczach" (Ernst 1988: 254). Odznaczała się dużą i wszechstronną inteligencją, a jej prawdziwym darem był talent językowy. Podczas studiów na rzymskim uniwersytecie Zofia swobodnie posługiwała się w mowie i w piśmie językiem angielskim i francuskim, zgłębiała także tajniki języka włoskiego. Dwudziestodziewięcioletni Jan w chwili poznania Zofii był już doktorem nauk rolniczych, od 9 grudnia 1937 roku przebywał w Rzymie na rządowym stypendium naukowym w Istituto Internazionale d'Agricoltura.

Okres pobytu w Rzymie był dla młodziutkiej Zofii czasem dynamicznych zmian w życiu osobistym. 29 kwietnia 1938 roku podczas pobytu na wycieczce w Taorminie Jan wyznał Zofii miłość, prosząc ją o rękę. W ostatnich dniach czerwca 1938 roku Zofia i Jan przyjechali do Warszawy, gdzie nastąpiła seria oficjalnych wizyt rodzinnych. Powzięcie przez Zofię i Jana wspólnej decyzji życiowej spotkało się z akceptacją obu rodzin, ślub został wyznaczony na 15 października 1938 roku w Warszawie, w kościele ojców

5 Jan Ernst (1909-1993), profesor geografii ekonomicznej w Uniwersytecie Marii Curie-Skłodowskiej w Lublinie. W latach 1927-1932 studiował geografię na Uniwersytecie Jana Kazimierza we Lwowie, początkowo pod kierunkiem prof. Eugeniusza Romera, a później prof. Augusta Zierhoffera. W roku 1932 uzyskał stopień magistra geografii, w roku 1938 tytuł doktora. W roku 1930 we Lwowie Jan Ernst utworzył własny zespół wokalny, czwórkę rewelersów nazwaną Chórem Eryana. Ernst przyjął wówczas artystyczny pseudonim Eryan (Ernst 1988, t. 1). 
Karmelitów na Krakowskim Przedmieściu. Ceremonię ślubną odprawił biskup Antoni Szlagowski, cioteczny brat ojca Zosi. Państwo młodzi po ślubie zamieszkali w alei Trzeciego Maja 7 w Warszawie.

Pomimo narastania napięcia międzynarodowego i groźby wybuchu wojny Jan i Zofia układali podwaliny wspólnego życia. Zaczęli brać udział w życiu kulturalnym stolicy, często chodzili do teatrów i na koncerty, nawiązywali kontakty towarzyskie, głównie z przyjaciółmi Zofii. Jan w roku 1938 podjął pracę w Głównym Urzędzie Statystycznym w Warszawie. Latem 1939 roku zdecydowali się na wyjazd do Dworzysk do majątku Janka Hewella, ciotecznego brata Zofii. W chwili wybuchu II wojny światowej Ernstowie znajdowali się we Lwowie u matki Jana. We Lwowie mąż Zofii został zmobilizowany i brał udział w kampanii wrześniowej jako oficer 19. pułku piechoty Odsieczy Lwowa. Zofia razem ze swoim bratem Wojciechem wyjechała ze Lwowa do Warszawy i przeniosła się do swoich rodziców na Mokotowską 53. Była wtedy w piątym miesiącu ciąży. Krzysztof, pierworodny syn Zofii i Jana, przyszedł na świat 14 stycznia 1940 roku. Podczas wojny Zofia i Jan nie utrzymywali zbyt szerokich kontaktów towarzyskich, serdeczne więzy przyjaźni ograniczyli do spotkań z Jerzym i Jadwigą Łozińskimi, a także z Zofią i Tadeuszem Bratkowskimi (przyjaźń z Zofią zawiązała się jeszcze podczas pobytu na studiach w Rzymie). W czasie okupacji Jan Ernst dorabiał jako pianista w warszawskich kawiarniach, Zofia Ernstowa wyjeżdżała w tym okresie kilkakrotnie do majątku wujostwa Geyerów Dąbrowy Zielonej, w pobliżu Częstochowy, tam też 28 sierpnia 1943 roku przyszedł na świat drugi syn Zofii i Jana, Tomasz. Upalne lato 1944 roku młodzi rodzice spędzili razem z dziećmi w Jabłonnie pod Warszawą, do stolicy powrócili 26 lipca. W Warszawie przy Mokotowskiej $53 \mathrm{w}$ rodzinnym domu Zofii przeżyli wybuch Powstania Warszawskiego, 9 września powzięli decyzję o wyjściu z oblężonej Warszawy, udali się do obozu przejściowego w Pruszkowie, z obozu udało im się wydostać tylko dzięki szczęśliwemu zbiegowi okoliczności i pomocy Ireny Panenkowej, bratanicy profesora Eugeniusza Romera, która w obozie była sanitariuszką i pamiętała Jana Ernsta ze Lwowa. 10 września Jan wraz z Zofią i dziećmi opuścili obóz i wyruszyli do Częstochowy, licząc na pomoc krewnych z Dąbrowy Zielonej.

Wiosną 1945 roku postanowili wyjechać z Dąbrowy Zielonej do Łodzi. Miasto nie było zniszczone i to tam koncentrowało się początkowo życie administracyjne, naukowe i kulturalne kraju. Mieszkanie mieli zapewnione na terenie fabryki Geyera. Zofia zajmowała się domem i wychowywaniem synów, w wolnych chwilach dużo czytała i starała się śledzić bieżące 
wydarzenia kulturalne. Jan próbował podjąć pracę, która zapewniłaby czteroosobowej rodzinie choćby niewielkie środki materialne. Grał na fortepianie w nocnych lokalach i próbował wskrzesić założony przed wojną we Lwowie Chór Eryana. Współpracował między innymi z Edwardem Atlasem, który bezpośrednio po wojnie zajmował kierownicze stanowisko w „Wojentorgu”, instytucji wojskowej organizującej restauracje i kawiarnie, głównie dla potrzeb armii. W tym okresie Jan i Zofia zaprzyjaźnili się z jednym z oficerów odpowiedzialnych za jeńców, z Włochem Aldem Nicolajem (późniejszym dramaturgiem), ich przyjaźń przetrwała do późnych lat osiemdziesiątych ${ }^{6}$.

Pomimo że Jan pracował popołudniami i wieczorami w łódzkich kawiarniach, Ernstowie zaczęli prowadzić coraz bardziej ożywione życie towarzyskie. Największa serdeczność w okresie łódzkim łączyła ich ze Stefą Biedrzycką, Jankiem Brzechwą ${ }^{7}$, małżeństwem Fiałkowskich ${ }^{8}$ i Stanisławem Kmitą 9 . Jan Brzechwa szczególnie polubił Zofię Ernst, imponowała mu inteligencją i urodą. Z kolei Jan Ernst napisał do tekstów Brzechwy szereg piosenek, które po wojnie wykonywał Chór Eryana. Zespół wznowił działalność w 1945 roku w Łodzi.

W maju roku 1946 Ernstowie wraz z dziećmi przeprowadzili się do Warszawy, gdzie Janowi zaproponowano stanowisko dyrektora planowania w Państwowej Centrali Handlowej. Rodzina zamieszkała początkowo w Skolimowie, skąd Jan dojeżdżał do pracy, dopiero jesienią 1946 roku udało im się wprowadzić do mieszkania na ulicy Mokotowskiej $53^{10}$. Dom był jednym z nielicznych w Warszawie, które nie zostały uszkodzone podczas II wojny światowej. Mieszkanie było duże $\left(150 \mathrm{~m}^{2}\right)$, ale w roku 1946 przepełnione, bo zamieszkane przez 28 lokatorów. Przez pierwsze dziesięć lat Zofia wraz z rodziną mieszkała w dwóch pokojach. Trudne warunki

${ }^{6}$ Aldo Nicolaj (1920-2004), dziennikarz, reżyser, dramaturg. Po wojnie pierwsze spotkanie Alda z Janem i Zofią miało miejsce z Rzymie w 1957 roku. Zofia Ernstowa przetłumaczyła na język polski dwuaktową komedię Nicolajego To nie była piąta, to była dziewiąta (Non era la quinta, era la nona), która miała premierę w styczniu 1977 r. w warszawskim Teatrze „Kwadrat”.

${ }^{7}$ Znajomość z Brzechwą była początkiem późniejszej, wieloletniej przyjaźni. Jan Brzechwa, znany już wówczas jako poeta, był „,motorem ożywionego, pełnego fantazji i humoru życia towarzyskiego" (Zob. Ernst 1988: 70).

${ }^{8}$ Gabriel Fiałkowski i jego żona Wiera byli z zawodu lekarzami.

${ }^{9}$ Lekarz laryngolog, daleki kuzyn Zofii Ernst.

${ }^{10}$ Kamienica została wybudowana w roku 1924, pierwszą właścicielką mieszkania była babcia Zofii, Brodowska. Od roku 1935 mieszkali w nim rodzice Zofii. 
materialne skłoniły ją w roku 1950 do podjęcia pracy w Polskim Radiu w dziale włoskim, na stanowisku tłumaczki języka włoskiego.

Na początku lat pięćdziesiątych Ernstowa zaczęła zajmować się zawodowo przekładami literatury włoskiej. Jej pojawienie się na scenie literackiej jest niewątpliwie związane z przemianami w polityce wydawniczej, które nastąpiły w Polsce po roku 1950 (Kondek 1993). Można domniemywać, że pomysł zajęcia się przekładami z literatury włoskiej mógł podsunąć Ernstowej ktoś z przyjaciół-literatów (najprawdopodobniej Jan Brzechwa), z kolei synowa Zofii Ernst wskazuje, iż bezpośrednią przyczyną podjęcia pracy tłumaczki była trudna sytuacja materialna rodziny Ernstów. Zofia Ernst zadebiutowała w roku 1953 przekładem nowel Giovanniego Vergi, który wykonała wspólnie z Marcinem Czerwińskim (Verga 1953). W tym samym roku wstąpiła do Związku Literatów Polskich (ZLP). W roku 1954 przetłumaczyła dla wydawnictwa Nasza Księgarnia pierwszą powieść dla dzieci, Opowieść o Cebulku, mało znanego jeszcze wtedy we Włoszech komunizującego pisarza - Gianniego Rodariego. Od tamtej pory Ernstowa chętnie współpracowała $\mathrm{z}$ potentatem w sektorze wydawnictw dla młodego czytelnika (Aleksandrzak 1972), ogłaszając kolejne przekłady Rodariego: Podróż Błękitnej Strzały (1955), Małych włóczęgów (1957), Bajki przez telefon (1967). Choć we wspomnieniach syna Zofii Ernstowej, Tomasza Ernsta, Opowieść o Cebulku zapisała się jako jedna z ulubionych książek dzieciństwa, to sama Ernstowa nie wspominała najbliższym o kulisach współpracy z Naszą Księgarnią, choć jej syn potwierdza, że z pracownikami wydawnictwa łączyły ją serdeczne kontakty. Z przeprowadzonych przeze mnie badań bibliograficznych wynika, że z wydawnictwem współpracowała do roku 1974 włącznie, ogłaszając przekłady ośmiu utworów, z których część była kilkakrotnie wznawiana (Biernacka-Licznar 2017: 27-29). Opracowane przez Ernstową przekłady utworów dla dzieci i młodzieży były w latach 60. i 70. chętnie wykorzystywane przez polskie teatry lalek, a także przez Teatr Polskiego Radia.

Począwszy od drugiej połowy lat pięćdziesiątych, Ernstowa zaczęła tłumaczyć coraz więcej, nawiązała współpracę z ważnymi i liczącymi się wówczas wydawnictwami: Czytelnikiem, PIW-em. Jej dorobek zyskał aprobatę i uznanie, a ona sama stopniowo zaczęła zdobywać opinię czołowego tłumacza literatury włoskiej na język polski. Należy jednak podkreślić, że w okresie działalności Zofii Ernstowej wśród warszawskich wydawców wielkim uznaniem cieszyła się także działalność przekładowa przedwojennej 
tłumaczki: Barbary Sieroszewskej (1904-1989), z którą Ernstowa od lat 50. pozostawała w serdecznych stosunkach.

Powojennym stosunkom towarzyskim Zofii i Jana sprzyjało wejście Zofii w świat literacki, jak również działalność Jana w życiu muzycznym i naukowym. W Warszawie do bliskiego grona przyjaciół Zofii Ernst należeli między innymi Jarosław Iwaszkiewicz, Jan Brzechwa, Julian Tuwim, Antoni Słonimski, ówczesny prezes ZLP. To dzięki staraniom Słonimskiego w drugiej połowie lat 50. udało się rodzinie Ernstów odzyskać trzy pokoje w mieszkaniu przy Mokotowskiej 53, gdzie chętnie bywali przyjaciele z warszawskiego środowiska literackiego.

Po roku 1956 Zofia zaczęła wyjeżdżać regularnie do Włoch w związku z pracą przekładową. Z każdym rokiem tłumaczyła coraz więcej, intensywnie współpracowała z Czytelnikiem i PIW-em, chętnie uczestniczyła w organizowanych przez wydawnictwa spotkaniach literackich. W 1958 roku otrzymała od pisarza Giorgia Bassaniego zaproszenie do Neapolu na październikowy Międzynarodowy Kongres Pisarzy, podczas którego Sindacato Nazionale Scrittori powołało do życia Europejską Wspólnotę Pisarzy (Comunità Europea degli Scrittori, ComES). Zofia Ernst była jedynym przedstawicielem polskiej delegacji.

W latach 1959-1970 pełniła funkcję sekretarza generalnego Sekcji Polskiej Europejskiej Wspólnoty Pisarzy, której była członkiem założycielem. Uczestniczyła jako polski delegat w spotkaniach Komitetu Wykonawczego ComES-u w Rzymie oraz w Międzynarodowych Kongresach ComES w Rzymie, Florencji, Taorminie, Atenach i Paryżu. Nawiązała kontakty z włoskim światem literackim i serdeczną przyjaźń z Elsą Morante, Guidem Piovenem, Giuseppem Marottą (Ciechanowicz 1992: 10). W roku 1960 ZLP zwrócił się do Zofii z propozycją, aby zechciała zaopiekować się słynnym dyrygentem amerykańskim polskiego pochodzenia Leopoldem Stokowskim podczas jego pobytu w Polsce. Poznanie Stokowskiego zaowocowało w późniejszych latach także licznymi kontaktami we Włoszech z osobami związanymi ze światem muzyki.

W roku 1961 w stulecie Zjednoczenia Włoch Zofia Ernst otrzymała odznaczenie „Medaglia della Direzione Generale delle Relazioni Culturali con l'Estero" za zasługi na polu szerzenia kultury włoskiej w Polsce. W marcu 1962 roku we Florencji odbył się kolejny kongres Europejskiej Wspólnoty Pisarzy. Uczestniczył w nim między innymi Jarosław Iwaszkiewicz, który na kartach Podróży do Włoch zawarł krótkie wspomnienie tego wyjazdu: 
Najprzyjemniejsze oczywiście były spotkania i rozmowy prywatne. Kochana pani Campetti przyjechała z Lukki, a z delegatów polskich najmilsi byli Międzyrzecki, urocza Zofia Ernstowa i najprzyjemniejszy człowiek, jakiego w życiu spotkałem, Jan Brzechwa (Iwaszkiewicz 2008: 72).

W roku 1963 kongres Europejskiej Wspólnoty Pisarzy odbył się w Warszawie, a Zofia Ernstowa była jednym z jego organizatorów (polski oddział Europejskiej Wspólnoty Pisarzy liczył wówczas 60 osób). W roku 1964 Zofia Ernst została przyjęta do PEN Clubu.

W latach 60. Ernstowie prowadzili w Warszawie ożywione stosunki towarzyskie, w ich mieszkaniu przy Mokotowskiej często gościli włoscy literaci, którzy zabiegali u Zofii o przekład swoich utworów. Okazją do spotkań towarzyskich z polskim światem literackim były między innymi coroczne wyjazdy na wakacje letnie do Ustronia Morskiego i zimą do Zakopanego, do domów wypoczynkowych Związku Autorów i Kompozytorów Scenicznych (ZAiKS). W tym okresie małżeństwo Ernstów często podróżowało także do Włoch, czasami w podróży towarzyszyli im synowie. W pamięci Ernstów ciepło zapisał się także pobyt w roku 1965 w Związku Radzieckim, do którego wyjechali na zaproszenie Jana Brzechwy i jego żony. Motywacją wyjazdu było honorarium autorskie Brzechwy, które mógł wydać tylko w ZSRR, dzięki niemu Brzechwowie i Ernstowie spędzili tydzień w Moskwie i cztery tygodnie w Domu Związku Literatów Radzieckich w Jałcie.

W latach 60. wydawnictwa chętnie powierzały Ernstowej przekłady współczesnych powieści włoskich ${ }^{11}$, ona sama zaczęła się specjalizować w literaturze autorów sycylijskich. Jej naczelną zasadą tłumaczenia było: „nie zdradzać autora, przeniknąć to, co chciał powiedzieć. Nie można niczego dodawać ani opuszczać" (Ciechanowicz 1992: 10). Zofia nadal kontynuowała podtrzymywanie i nawiązywanie kontaktów z włoskimi literatami. W roku 1967, w drodze powrotnej z Kanady ${ }^{12}$, małżeństwo Ernstów

11 W latach 1953-1959 Zofia Ernst przetłumaczyła 12 utworów z języka włoskiego, w latach 1960-1969 opublikowano 28 utworów włoskich w jej przekładzie, w latach 19701979 przetłumaczyła 12 utworów. Opracowano na podstawie danych dostępnych na stronie Biblioteki Narodowej.

12 Podstawą obu wyjazdów do Kanady było zaproszenie Zofii i Jana przez ciotkę Geyerową, która gościła małżeństwo Ernstów podczas okupacji w Dąbrowie Zielonej. Pod koniec wojny ciotce udało się wyjechać z mężem i dziećmi do Szwajcarii, skąd wyemigrowała do Brantford w Kanadzie. Na podstawie: Ernst 1988, t. 2: 201. 
zatrzymało się we Włoszech na Riviera di Ponente, u bliskich znajomych: Ambrogia i Mali Devotów, Ambrogio był wówczas prezesem Związku Autorów Włoskich. Następnie Ernstowie udali się w odwiedziny do Marcella i Camilli Venturich ${ }^{13}$ (Ernst 1988, vol. 2: 190-191).

Ernstowa czynnie uczestniczyła w kształtowaniu obrazu włoskiej literatury w Polsce. W wywiadzie udzielonym w roku 1974 Eugeniuszowi Kabatcowi dla Literatury na Świecie opowiadała o pracach w komisji powołanej przez Klub Tłumaczy Związku Literatów Polskich, którego zadaniem było zbadanie „stanu nasycenia naszej świadomości kulturalnej przekładami z literatur obcych" (Kabatc 1974: 383). Tłumaczka wspominała o opracowanych przez Klub Tłumaczy listach najważniejszych pozycji i propozycji, które zostały przedstawione Ministerstwu Kultury jako postulaty, z nadzieją, że część z nich uda się zrealizować. To wtedy Ernstowa zarekomendowała do tłumaczenia między innymi De Sanctisa, Alvara, Monellego ${ }^{14}$, Bontempellego, Federica De Roberta. Świadomie wprowadziła na polski rynek wielu wybitnych autorów włoskich, czuła się odpowiedzialna za kształtowanie w Polsce obrazu literatury włoskiej. Uważała, że w okresie powojennym w Polsce traktowano sprawy literatury włoskiej w sposób należyty, podkreślała, że do roku 1974 przedstawiono polskiemu czytelnikowi ponad stu autorów włoskich, co plasowało włoską literaturę dla odbiorcy dorosłego w czołówce literatur zachodnich wydawanych w Polsce.

W roku 1961 otrzymała włoskie odznaczenie za zasługi na polu szerzenia kultury włoskiej w Polsce. W latach 1969, 1971 i 1988 otrzymała Premio di Cultura della Presidenza del Consiglio za przekłady literatury włoskiej na język polski. Przyznanie Zofii Ernstowej jednej z nagród tak zapisało się we wspomnieniach Eugeniusza Kabatca:

miałem okazję świętować z Zofią Ernst jedną z nagród, przyznaną z inicjatywy Giuseppe Padellara, dyrektora generalnego w Prezydium Rady Ministrów. Padellara cieszył się osobiście z docenienia przez włoską Radę Ministrów działal-

${ }_{13}$ Powieści Marcella Venturiego ukazywały się w Polsce od roku 1964, Droga powrotna w przekładzie Wandy Gall, Biała flaga nad Kefalinia (1968), Ostatni żaglowiec (1972), Ostatnia stacja (1972) w przekładzie Sieroszewskiej. Na podstawie: http://katalogi.bn.org. $\mathrm{pl} /$ iii/encore/search/C_Smarcello\%20venturi_Orightresult_U?lang=pol\&suite =cobalt (dostęp: 12.02.2018).

${ }_{14}$ Monelli niejednokrotnie wskazywał Ernstowej utwory z literatury włoskiej, które powinna przetłumaczyć. Na podstawie: Ciechanowicz 1992: 10. 
ności przekładowej Zofii Ernstowej, tym bardziej, że w roku 1971 w Polsce za sprawą Ernstowej ukazała się książka Padellary Tryptyk sycylijski ${ }^{15}$.

W 1985 roku ZAiKS uhonorował Zofię Ernst nagrodą za działalność przekładową, a w roku 1991 Włoski Instytut Kultury w Warszawie przyznał jej nagrodę imienia Canaletta (Mikołajewski 1994). W roku 1993 Zofia Ernst otrzymała z rąk Ministra Kultury i Sztuki Rzeczpospolitej Polskiej gratulacje i wyrazy uznania dla swoich dokonań translatorskich w dziedzinie przekładów wybitnych dzieł literatury włoskiej i za zasługi dla popularyzacji wśród polskich czytelników takich pisarzy, jak Alberto Moravia, Giuseppe Tomasi di Lampedusa, i Italo Svevo.

W roku 1993 zmarł Jan Ernst, rok później, 3 sierpnia, odeszła Zofia. W roku 2016 kapituła Nagrody Literackiej im. Leopolda Staffa przy Antich' Caffè w Warszawie przyznała Zofii Ernstowej nagrodę „In memoriam”"16.

Zofia Ernst ofiarowała polskim czytelnikom ponad pięćdziesiąt tytułów najwybitniejszych autorów włoskich: między innymi Alberta Moravii, Itala Sveva, Giovanniego Vergi, Vitalina Brancatiego, Federiga Tozziego, Giuseppe Marotty, Guida Piovenego czy Leonarda Sciasci. W swojej działalności translatorskiej nie zapomniała także o dzieciach i młodzieży, to dzięki niej pojawiła się w Polsce twórczość Gianniego Rodariego, Giovanniego Moski, Baccio Marii Bacciego i Marcella Argillego. Jej najukochańszą książką był Lampart Tomasiego di Lampedusy; był to jedyny przekład, z którego była naprawdę dumna ${ }^{17}$. Tłumaczyła także wystawiane w polskich teatrach sztuki sceniczne, między innymi Daria Fo, Giana Paola Callegariego czy wspomnianego już Alda Nicolajego. Z języka polskiego przetłumaczyła na język włoski dramat Karola Wojtyły zatytułowany Brat naszego Boga (Ioannes Paulus 1982), który ukazał się we Włoszech w roku 1982. Upływający czas, odejście męża spowodowały, iż nie dokończyła przekładu I viceré Federica De Roberta, który pozostał w rękopisie w mieszkaniu przy Mokotowskiej 53.

${ }^{15}$ Wspomnienie to zostało przekazane autorce artykułu przez Eugeniusza Kabatca w formie maszynopisu w maju 2017 roku.

${ }^{16}$ Do nagrody w kategorii In memoriam mogą być nominowani wybitni nieżyjący autorzy piszący o Włoszech lub tłumacze literatury włoskiej; http://antichcaffe-nagrodaliteracka. pl/o-nagrodzie/ (dostęp: 12.08.2018).

17 T. di Lampedusa, Lampart, przekład Zofia Ernstowa, Warszawa: PIW 1961. Utwór był w kolejnych latach wznawiany $(1963,1967,1970)$, w roku 1988 książka ukazała się nakładem wydawnictwa KiW, w 1993 nakładem Wydawnictwa Dolnośląskiego, w 2001 i 2002 nakładem wydawnictwa Muza z Warszawy. 
Odtwarzając koleje życia Zofii Ernstowej miałam w pamięci epokę, w której przyszło jej żyć. Jej lata młodzieńcze przypadły na okres dwudziestolecia międzywojennego. Staranne wychowanie i wyniesiona z domu znajomość języków obcych zadecydowały o jej późniejszym życiu zawodowym. Lata powojenne upłynęły jej na intensywnej działalności przekładowej, którą wykonywała z ogromną pasją i zaangażowaniem. Doskonale orientowała się w głównych tendencjach powojennego programu przebudowy państwa polskiego i skutecznie dążyła do zaistnienia i nawiązania kontaktów z osobami odpowiedzialnymi w tym okresie za odbudowę kultury w Polsce, a także za nawiązywanie i umacnianie stosunków kulturalnych pomiędzy Polką i Włochami (m.in. poprzez kontakty z Iwaszkiewiczem, Kabatcem).

Jej działalność zawodowa, która przypadła na lata 1953-1979, była przede wszystkim związana z jednym konkretnym miejscem - Warszawą, choć na mapie jej aktywności nie zabrakło także innych miast polskich i zagranicznych, w których pielęgnowała kontakty towarzyskie, promowała literaturę włoską, dbała o kontakty literackie polsko-włoskie. Była osobą energiczną, czynnie zaangażowaną w promocję kultury. Inspirację do swojej pracy twórczej czerpała niejednokrotnie z bliskich kontaktów z polskim środowiskiem literackim.

Jej działalność translatorska odegrała dużą rolę na polskim rynku przekładów literatury włoskiej. Zofia Ernstowa lubiła pochylać się nad arcydziełami literatury włoskiej, czasami świadomie dobierała utwory do tłumaczenia, za jej pośrednictwem polscy czytelnicy poznali Moravię, Sveva, Tozziego. Zabiegała o publikację Sciascii, Morante, Piovenego. Powierzone jej zadania wykonywała z pasją, pokazując iż ,żadne dzieło sztuki, choćby maleńkie, nie rodzi się z obojętności” (Ciechanowicz 1992).

Była dociekliwa, ironiczna, a zarazem ciepła, odznaczała się żywą inteligencją, która pozwoliła jej w trudnych latach powojennych zadbać o dom rodzinny i najbliższych. Fascynowała ludzi, szczególnie mężczyzn, swoim urokiem, wdziękiem, polotem, a ona sama darzyła wielką przyjaźnią Iwaszkiewicza, profesora Mieczysława Brahmera, z którym pozostawała w żywych kontaktach ${ }^{18}$. Pod koniec życia lubiła wspominać Brzechwę, Ludwika Perskiego, Artura Międzyrzeckiego i wielu innych, których często spotykała w PEN Clubie bądź w ZLP.

${ }^{18}$ W taki sposób zapamiętała Zofię Ernst jej synowa Maria Ernst. Opracowano na podstawie wywiadu telefonicznego przeprowadzonego 1.09.2017. 
Zofia Ernstowa jest postacią niezwykle zasłużoną dla relacji polsko-włoskich, a jej działalność zawodowa przyczyniła się do zbudowania trwałych kontaktów kulturalnych pomiędzy obu krajami.

\section{Bibliografia}

Aleksandrzak S. (red.). 1972. Pół wieku Przyjaźni z Dzieckiem i Szkoła 1921-1971. Warszawa: Nasza Księgarnia.

Bernatowicz G. 1990. Stosunki polsko-włoskie 1944-1989. Warszawa: Polski Instytut Spraw Międzynarodowych.

Biernacka-Licznar K. 2016. Le traduzioni polacche della letteratura italiana per l'infanzia negli anni 1887-1939, „Kwartalnik Neofilologiczny” LXIII, 4, s. 460-468. - 2017. Zofia Ernst (1918-1994): l'arte di vivere, l'arte di tradurre, „Italica Wratislaviensia" 8(2), s. 11-36.

Ciechanowicz J. 1992. Kolory Włoch. Rozmowa z Zofia Ernstowa, ttumaczka literatury wtoskiej, „Życie Warszawy”, 21-22 marca, s. 10.

Czachowska J., Szałagan A. (red.). 1994. Współcześni polscy pisarze i badacze literatury. Słownik biobibliograficzny, t. 2. C-F. Warszawa: WSiP, s. 259-261.

Dam H.V., Korning Zethsen K. 2010. Translator Status. Helpers and Opponents in the Ongoing Battle of an Emerging Profession, ,Target” 22(2), s. 194-211.

Ernst J. 1988. Dwie linie życia, t. 1, 2, Lublin: Wydawnictwo Lubelskie.

Ioannes Paulus. 1982. Il fratello del nostro Dio, Città del Vaticano: Libreria Editrice Vaticana.

Iwaszkiewicz J. 2008. Podróże do Włoch. Warszawa: Państwowy Instytut Wydawniczy. Kabatc E. 1974. O przektadach z literatury wloskiej - z Zofia Ernstowa, „Literatura na świecie" 1(33), s. 383-387.

Kondek S.A. 1993. Władza i wydawcy. Polityczne uwarunkowania produkcji książek $w$ Polsce w latach 1944-1949. Warszawa: Biblioteka Narodowa.

Kvale S. 2012. Prowadzenie wywiadów. Warszawa: Wydawnictwo Naukowe PWN. Mikołajewski J. 1994. Pożegnanie. Zofia Ernstowa, „Gazeta Wyborcza”, 1.09.1994. Miłosz Cz. 1999. Przekłady i Gałczyński, w: Cz. Miłosz, Kontynenty, Kraków: Znak.

Pasztor M., Jarosz D. 2013. Skazani na podległość. Z dziejów stosunków polsko-włoskich w latach 1945-1958. Warszawa: Oficyna Wydawnicza ASPRA-JR.

Porębska M. 2017. Zofia Jachimecka (1886-1973). Życie i twórczość. Niepublikowana rozprawa doktorska, http://repozytorium.ur.edu.pl/handle/item/2296.

Rajewska E. 2015. Twórczość przekładowa kobiet, w: E. Kraskowska, B. Kaniewska (red.), Polskie pisarstwo kobiet w wieku XX: procesy i gatunki, sytuacje i tematy. Poznań: Wydawnictwo Naukowe UAM, s. 269-298.

Risku H., Windhager F. 2013. Extended Translation. A Sociocognitive Research Agenda. „Target” 25(1), 33-45. 
Rybicka E. 2008. Od poetyki przestrzeni do polityki miejsca. Zwrot topograficzny w badaniach literackich, „Teksty Drugie” 4, s. 21-38.

Solová R. 2015. Évolution du statut du traducteur assermenté en Pologne - une perspective sociologique, w: E. Skibińska, R. Solová, K. Gostkowska (eds.).Vingt cinq ans après... Traduire dans une Europe en reconfiguration, Paris: Orizons, s. 311-324.

Tomasi di Lampedusa G. 1961. Lampart, przekład Zofia Ernstowa, Warszawa: PIW.

Tuwim J. 2008. Pegaz dęba. Warszawa: Iskry.

Verga G. 1953. Don Candeloro i jego trupa. Nowele, przeł. Z. Ernstowa, M. Czerwiński. Warszawa: Czytelnik.

\section{Strony internetowe}

http://antichcaffe-nagrodaliteracka.pl/laureaci-2016/ (dostęp: 22.02.2018).

http://katalogi.bn.org.pl/iii/encore/search/C_Smarcello\%20venturi_Orightresult_U ?lang=pol\&suite=cobalt (dostęp: 22.02 .2018$)$.

https:/www.1944.pl/powstancze-biogramy/wojciech-kostanecki,22890.html (dostęp: 22.02.1018). 